celok. Kniha je tematicky vel'mi dobre komponovaná, aj ked' tlačiarenský škriatok aj tu urobil svoje dielo. Najviac je tým postihnutá siedma kapitole, v ktorej sa obsah na s. 6 nie celkom zhoduje so samotným obsahom v knihe. Celkovo však ide o knihu, ktorá rozhodne obohatí každú intelektuálnu knižnicu.

Tomáš Pružinec

\title{
Literatúra
}

NOVOSÁD, F. (2016) Osud a vol'ba. Max Weber o modernej spoločnosti. Bratislava: IRIS.

Doc. PhDr. ThDr. Tomáš Pružinec, PhD.

Univerzita Konštantína Filozofa v Nitre

Filozofická fakulta

Katedra filozofie

Hodžova 1

94901 Nitra

Slovenská republika

tpruzinec@ukf.sk

\section{Zlatica Plašienková (ed.): Bioetické výzvy a súčasnost'}

Bratislava, Stimul 2015, 287 s.

Súčasná bioetická problematika spojená s rýchlym rozvojom biotechnológií, biomedicínskeho a enviromedicínskeho výskumu, genetického inžinierstva a nanotechnológií, je charakterizovaná nielen interdisciplinaritou, ale aj názorovou a metodologickou pluralitou. $V$ minulom roku vyšla $v$ univerzitnom vydavatel'stve Stimul publikácia s názvom Bioetické výzvy a súčasnost', ktorá je výstupom vedecko-výskumnej aktivity 2.7 Spoločenské výzvy pre 21. storočie - bioetické výzvy $v$ kultúrnom rámci ${ }^{1}$. Recenzovaná publikácia je zborníkom obsahujúcim 24 odborných štúdií od 27 autorov a autoriek. Príspevky v tejto publikácii sú rozdelené do štyroch tematických celkov, čím sa zvyšuje zrozumitel'nost' a prehl'adnost' celého diela. Bioetická problematika je nazeraná z rôznych uhlov pohl'adu, a to práve podl'a odborného zamerania autorov. Otázky ohl'adne moderných trendov, ktorými

\footnotetext{
1 Aktivita je súčast'ou OP Výskum a vývoj pre dopytovo-orientovaný projekt: Univerzitný vedecký park Univerzity Komenského v Bratislave, ITMS 26240220086, ktorý je spolufinancovaný zo zdrojov Európskeho fondu regionálneho rozvoja.
} 
sa zaoberá súčasná bioetika, sú takto nazerané z pohl’adu filozofie, teológie a religionistiky, etnológie a kultúrnej antropológie, či epistemológie a informačných štúdií.

V prvej časti nájdeme odbornú štúdiu samotnej editorky zborníka, Z. Plašienkovej, s názvom Bioetická problematika s dôrazom na vylepšovanie človeka v kontexte liberálnej eugeniky. Autorka sa tu dotýka etických aspektov vylepšovania človeka a konštatuje, že dnes už nie je otázkou či človeka vylepšit', alebo nie, no ako píše, otázkou už je „ako a kedy ho vylepšit" (s. 63). Môžeme konštatovat', že technologický a biotechnologický pokrok sl'ubuje l'udstvu priam fantastickú budúcnost'. Zaujímavou konkretizáciou danej témy sú aj príspevky od P. Kreta Reprodukčné klonovanie a J. Viglaša Etické výzvy a úskalia plastickej chirurgie. $\mathrm{V}$ danej súvislosti sa môžeme spolu s E. Višňovským a jeho štúdiou Filozofický problém dobrého života v ére biotechnológií oprávnene pýtat': „Kam smeruje technologický pokrok? Čo prináša l'udstvu? Ako technológia mení povahu l’udského života?" (s. 10). Inými slovami, sú to otázky týkajúce sa chápania toho, v čom spočíva dobrý život človeka a aké sú predstavy l'udí o dobrom živote vôbec.

Uvedené otázky súvisia nielen s problematikou technologickej, ale aj sociálnej regulácie, čo znamená, že ide taktiež o otázku distribúcie bohatstva v spoločnosti. Odzrkadl'uje sa to aj v nerovnomernom „pridel'ovaní“ technických výdobytkov, chudobou niektorých vrstiev obyvatel'stva a znižujúcou sa životnou úrovňou. Antický ideál kalokagathie, ako o ňom píšu E. Mistrík a K. Minarovičová v príspevku s názvom Ako sa pripravit' na výsledky biomedicínskeho výskumu, je už dávno zabudnutou ideou. V súčasnosti sa kladie dôraz na telo, ktoré dobre vyzerá - nie na telo, ktoré je zdravé. Vznikajú ideály krásy založené na matematických výpočtoch odtrhnuté od každodennej reality. Akoby človek plával na vode - telo podlieha módnym trendom rovnako ako oblečenie, ktoré nosíme na jeho zahalenie. „Plávanie na vode" sa dotýka aj morálnych princípov, ktoré nepriamo s vnímaním krásy súvisia. Je naozaj t’ažké zaujat' etické stanovisko voči trendom, ktoré sa vo svete objavujú, no zároveň sú často debaty týkajúce sa bioetických princípov odzrkadlením slabých morálnych základov, ktoré v kultúre máme. Absencia pevných morálnych princípov potom vedie k rozpadu kultúrnych základov. Na to, aby bol vývoj spoločnosti možný, je potrebný pevný stred, o ktorý sa dá opriet'. V tomto smere môže byt' nápomocná aj diskurzívna analýza bioetickej problematiky v rámci populárnej kultúry a masmédií, o čom svedčí štúdia autoriek O. Orgoňovej a A. Bohunickej Diskurzná produkcia transrodovej identity v slovenskom kultúrnom rámci.

Ďalší morálny problém v kontexte biomedicíny, na ktorý vo svojom príspevku s názvom Princíp autonómie v bioetike poukazuje L. Bohunická, je rozpad paternalizmu, ktorý kedysi fungoval v oblasti medicíny vo vzt'ahu lekár - pacient. V tomto vzt’ahu existovala asymetria, no bola chápaná ako legitímna. Lekár bol intelektuálnou elitou a zároveň morálnou autoritou. Uvedomenie si vlastných slobôd a l'udských práv viedlo postupne k zániku paternalizmu a k nastoleniu vzt'ahu za- 
loženom na autonómii pacienta, t. j. na práve každej l’udskej osoby na sebaurčenie. Postmoderna je charakterizovaná vysokou pluralitou názorov, čo sa odráža aj v rôznorodých etických prístupoch. Neblahým dôsledkom tohto pluralizmu je dôraz na právne regulácie. Dalo by sa zhrnút', že nedostatok vnútornej regulácie, t. j. regulácie pochádzajúcej z vnútorných presvedčení l'udí, musí byt' ošetrený umelo vytvorenou jednotnost'ou. Aj reflexia takýchto legislatívnych problémov je v zborníku prítomná a čitatel' sa môže nechat' inšpirovat’ otázkami, ktoré autori nastol'ujú - napr. autorka Z. Kiczková v štúdii s názvom Normatívny rámec etiky starostlivosti, autorka M. Ujházyová v príspevku Etický a právny rámec personalizovanej medicíny alebo autor B. Fábry v príspevku s názvom Biotechnologické výzvy a nedostatky právnej regulácie.

V druhej časti zborníka sa stretávame s príspevkami k problematike bioetiky z pohl'adu teológie a religionistiky. Autormi prispievajúcimi do tohto bloku sú R. Kečka so zaujímavou štúdiou Komparácia bioetických postojov vybraných krest'anských cirkví, M. Neština s príspevkom Miesto sekulárneho argumentu Dona Marquisa proti interupciám vo verejnej sfére z hl'adiska koncepcie verejného rozumu Johna Rawlsa a M. Zaviš s textom Bioetická problematika v religionistickom kontexte: súčasný postoj šaríe $k$ vybraným metódam asistovanej reprodukcie. Ďalšou zo štúdií tohto bloku, v ktorej sa tematicky rozoberá otázka interrupcie a toho, kedy od počatia nového jedinca môžeme hovorit' o l'udskej bytosti, je štúdia evanjelického teológa L'. Batku Prirodzený zákon a bioetika z pohl'adu evanjelickej etiky. Autor v nej prízvukuje, že krest'anstvo v žiadnom prípade netvrdí, že má patent na etiku. Existujú rovnaké etické štandardy pre veriacich aj pre neveriacich a dôraz sa tu kladie na diskusiu oboch strán. Základom je uvedomenie si skutočnosti, že dobro spoločenstva stojí vždy nad dobrom jednotlivca. V tomto fakte sa odráža aj problematika privátnej morálky verzus verejnej morálky, o ktorej píše trojica autorov M. Vivoda - V. Žufková - M. Koláček v štúdii s názvom Ku kritike sekulárnej bioetiky H. T. Engelhardta vzhl’adom na súčasnú technokratickú spoločnost'. Azda najdôležitejším pojmom, ktorý sa v tejto tematickej časti zborníku skloňuje zo všetkých strán, je pojem tolerancia. Je potrebné zdôraznit', že napriek náboženským inšpiráciám, ktoré v článkoch nájdeme, sú závery autorov prijatel'né aj pre ateistov.

Tretia čast' recenzovanej publikácie sa venuje bioetickým otázkam, ktoré sa týkajú etnológie a antropológie. M. Botíková a T. Bužeková píšu v štúdii Etnologicko-antropologická dimenzia výskumu zdravia a chorôb o tzv. medicínskej antropológii, ktorá skúma vzt'ahy medzi kultúrou a l’udským správaním súvisiacim so zdravím a chorobami. Zároveň však poukazujú na to, že na našom území chýba ucelená medicínska antropológia a k poznatkom tohto typu sa dostávame primárne cez folkloristiku. Chorobu tela autorky definujú ako formu komunikácie medzi prírodou, spoločnost'ou a kultúrou. Okrem toho poukazujú na skutočnost', že samotné prežívanie zdravia a choroby sa od kultúry ku kultúre líši. Problema- 
tizuje sa tu otázka - čo je zdravé? Formulácia tejto otázky je dôležitým príspevkom autoriek a odkrýva rovinu, ktorú je potrebné v rámci bioetickej problematiky reflektovat'. T. Bužeková sa vo svojom samostatnom príspevku s názvom Hanba a móres: Normy súvisiace s životným cyklom ženy v rurálnom prostredí venuje určitým typom emócií, najmä hanbe a tzv. „móresu“. Hanba pri niektorých druhoch správania je údajne indikátorom „znesvätenia“ kultúrnych noriem. V tejto súvislosti poukazuje na to, že morálka má kultúrne variácie, pretože morálne myslenie a kultúrne praktiky sa vyvíjajú súbežne. H. Hlôšková vo svojom príspevku pod názvom Tematika tela a zdravia vaktuálnom mediálnom diskurze folkloristický pohl'ad akoby nadväzovala na úvahy o mýte krásy z prvej časti zborníka, ked' píše, ako sa zábavnost' a navodzovanie príjemných pocitov stali základnými črtami populárnej kultúry. Tieto znaky sa postupne pretavujú do všetkých oblastí l'udského života, akými sú vzdelávanie, umenie, ale aj veda. Ak sa mení kvalita našej kultúry, mení sa tým pádom aj kvalita nášho morálneho zmýšl’ania. Znovu sa tu dostávame ku kríze morálnych základov v súčasnosti, ktorá bola akoby implicitným záverom prvej časti zborníka.

V poslednej, štvrtej časti sa stretávame s tematizáciou prepojenia vedeckej komunity so širšou verejnost'ou. Verejnost' trpí nedostatkom vedeckých informácií, a práve preto je nevyhnutné rozvíjat’ obojstranný dialóg medzi dvoma spomenutými stranami - píšu vo svojom príspevku Veda a verejnost': Premeny spôsobov tvorby poznania a ich vzt'ahovania $k$ verejnosti M. Szapuová a M. Nuhlíček. Úlohou vedy by nemala byt' iba produkcia poznania. Veda by mala brat' ohl'ad aj na spoločenské hodnoty, ktoré sú rovnocenné s vedeckými hodnotami. Je potrebné zohl'adňovat' morálne a sociálne kontexty rozhodnutí súvisiacich s vedou a výskumom. V minulosti bol kontext poznania oddelený od kontextu využívania nových poznatkov, no práve tento moment je nutné v modernej dobe prediskutovat'. Prenikanie vedeckého poznania do spoločenských štruktúr a prekračovanie disciplinárnych hraníc je zjavné aj vznikom nových typov organizácií, akými sú thinktanky, národné centrá výskumu a vývoja, vedecko-technologické parky a iné. Híbkovú analýzu moderných trendov informačnej vedy zameraných na podporu rozvoja a konceptualizácie otvorenej vedy v digitálnom prostredí približuje štúdia J. Steinerovej pod názvom Otvorená veda a digitálna veda z pohl'adu informačnej ve$d y$. Viacerí autori tematizujú okrem iného aj stratu dôvery verejnosti vo vedu, ktorá je spojená so vznikom nových biotechnológií a biomedicíny. V danom kontexte treba mat' na pamäti, ako uvádza J. Dolník v štúdii Orientácia v sociovedeckej xenosituácii, že styk vedy s verejnost'ou je zvláštnym prípadom interkultúrnej komunikácie, v ktorej sa stretáva kultúra vedeckej society a kultúra verejnosti. J. Šušol vidí riešenie v profesionálnej informačnej činnosti, ktorá by podporila participáciu verejnosti na vedeckých výsledkoch a kolaboráciu oboch spomenutých strán, ako sa dá vyčítat' v jeho príspevku Veda a technika ako strategická priorita $v$ dokumentoch a programoch Európskej únie. 
S týmito a s mnohými d’alšími myšlienkami sa stretne čitatel', ktorý vezme do rúk publikáciu Bioetické výzvy a súčasnost'. Napriek rozsahu 304 strán ide o čítanie, ktoré aktuálnost'ou svojho obsahu pobáda prelúskat' knihu „na jeden dych“. Aj ked' ide o odbornú literatúru, a nie beletristickú, po dočítaní poslednej stránky zotrváva pocit, akoby sa „príbeh ešte neskončil“. Oceňujem aj členenie zborníka, ktoré výrazne prispelo k tejto skutočnosti. Okrem iného pertraktovaná problematika nás vyzýva uvedomovat' si mnohoraké súvislosti, ktoré nie sú na prvý pohl'ad zjavné. Z tohto pohl'adu môže byt' publikácia nápomocná pri tvorbe vlastného bioetického stanoviska $v$ situáciách, ktorých problematickost' $v$ rovine etiky si všimneme až po dlhšom nazeraní. Rovnako môže rozšírit’ horizont odborníkov z rôznych oblastí, ktorí sa venujú bioetickej problematike. Nezanedbatel'ným prínosom je tiež jej využitie vo výučbe bioetickej problematiky na rôznych typoch vysokých škôl.

Kristína Kmet’ová

\section{Mgr. Kristína Kmet'ová}

Univerzita Komenského v Bratislave

Filozofická fakulta

Katedra filozofie a dejín filozofie

Šafárikovo námestie 6

81499 Bratislava 1

Slovenská republika

kristina.kmetova@uniba.sk

\section{Sucharek, P. (ed.).: Fenomenológia stretnutia}

Prešov, Filozofická fakulta Prešovskej univerzity, 2015, 159 s.

Monografia Pavla Suchareka je zložená z troch častí: z úvodnej autorskej štúdie Existenciálna fenomenológia Henriho Maldineyho v kontexte starosti o seba, a z dvoch prekladov: K fenomenológii stretnutia od holandského biológa, antropológa, psychológa a filozofa F. J. J. Buytendijka a Náčrt fenomenológie umenia od francúzskeho fenomenológa Henriho Maldineyho.

Štúdia P. Suchareka plní funkciu úvodu do problematiky a zároveň je premostením oboch nasledujúcich prekladov. Autor sa v nej zaoberá problematikou starosti o seba s jej dejinno-filozofickými koreňmi v platónskej starosti o dušu. Starost' o seba je pertraktovaná cez fenomenologickú prizmu a prepája filozofickú dimenziu s psychoterapiou a umením. 